\title{
Connecting Lockeian Social Contract Theory to the Crisis of Democratic Governance in Nigeria's Fourth Republic
}

\author{
Samuel B. Kalagbor (Ph.D) ${ }^{1}$ Preye Kuro Inokoba (Ph.D $)^{2}$ \\ 1. Port Harcourt Polytechnic, Department of Public Adminiistration, Rumuola, Port Harcourt, Rivers State \\ Nigeria \\ 2. Department of Political Science, Niger Delta University, PMB 071, Wilberforce Island, Bayelsa State, Nigeria
}

\begin{abstract}
It is a well acknowledged fact that twenty years into the Fourth Republic, Nigeria is still grappling with the delivery of the socio-economic and political benefits or dividends of democratic governance; socio - economic welfare, justice, equity and equal access to the country's resources and power - to the citizens of the country. This persistent phenomenon of ineffective and undemocratic governance has made scholars to severally describe Nigeria's democracy as "ailing", "fledging", "nascent", "illiberal", etc. To explain this crisis of democratic governance, the paper mainly attributed it to the absence of the fundamental democratic principles espoused by the Lockeian conception of the social contract. Thus, the main argument of the study is that the absence of the Lock's Social Contract democratic tenets in the practice of democracy in Nigeria is largely responsible for the ailing condition of the country's democratic experience. To achieve its objective, the paper employed the elite theory and descriptive method of analysis to examine data derived from secondary sources. The paper concludes that for the country to make any meaningful process in democratic governance, deliberate measures need to be taken to strengthen democratic institutions in order to curb the excesses of the managers of the political system in Nigeria.
\end{abstract}

Keywords: Lockes' Social Contract Theory, Democratic Governance, Fourth Republic, Consent, Representative Democracy, Rule of law.

DOI: $10.7176 / \mathrm{DCS} / 10-2-07$

Publication date: February $29^{\text {th }} 2020$

\section{Introduction}

Democracy as a concept and system of government may be bedevilled by definitional ambiguity, but there is a general consensus amongst scholars that it is a governance system that is fundamentally built and sustained by the consent and participation of the citizenry. It is widely acknowledged as a limited constitutional political structure that is based on the consent of the people subject to the constitution and the rule of law. The powers of a democratic government are limited because it is derived from the people as well as the law of the land (Omenka \& Akaan, 2013; Mukherjee \& Ramaswany, 2012; Paki \& Inokoba, 2006; Enemuo, 1999). Invariably, the sustainability, health and stability of any democracy including that of Nigeria largely depends on the continuous consent, trust and support of its citizenry.

However, the enthronement of democracy in Nigeria since 1999 is presenting a contradictory scenario. This is evident of the fact that all known indispensable values and tenets of democracy are either being compromised or jettisoned and the Nigerian state is fast sliding into a failed democratic state; a product of the mismanagement of democracy in the Fourth Republic. Twenty years into the Fourth Republic, democratic governance, is being afflicted with several maladies which includes widespread impunity among political office holders, electoral fraud and crimes, brazen corruption, prevalence of the rule of men instead of the rule of law, abuse of judicial processes, inability (or unwillingness) of governing class to meet the welfare needs of Nigerians and lack of socio-economic and political equity and justice. The persistent nature of undemocratic politics and governance has made scholars to severally describe Nigeria's brand of democracy as "ailing", "fledging", "nascent", "illiberal", "elitist", "plutocratic" among several other derogatory titles.

The paper in its attempt to explain the unending challenges to democracy in Nigeria focused on the contributions of Lockes' Social contract theory to the tenets and ideals of contemporary constitutional democracy. Though we are not unaware of the several criticisms and interpretations of Lockeian social contract mode of reasoning, our primary objective in this discourse is to unveil the democratic character of Locks' conception of the social contract and more importantly, employ this theoretical paradigm to explain the maladies afflicting democracy in Nigeria's Fourth Republic. Our assumption is that the absence of Lockeian social contract democratic principles in the practice of democracy in Nigeria is what responsible for the crisis of democratic governance in the country. It is also imperative to emphasize here that we are not concerned with the issue of the re-examination and re-construction of the foundations of the Nigerian state, rather the focus of the paper is on the relevance of the Lockes' construction of the social contract to the consolidation and deepening of democratic practice in Nigeria.

Though there are several versions of social contract theories such as that of Grotius, Hobbes, Spinoza, 
Pufendorf, Rousseau and Kant, the Lockean model was chosen because it has the most developed idea of limited constitutional government based on the consent of the people. Lockes' concepts of constitutionalism, tolerance, natural rights, limited and law - based political authority are some of the indispensible ingredients of modern day representative democracy. Again, Lockes' construction of the doctrine of divine right which led to the rise of the contract theory paved the way for the emergence of a limited constitutional state followed by declaration of rights, the Bill of Rights in 1688, thus drawing out a new relationship between the state and the individual. It is also widely acknowledged that the American and the French Revolutions and the constitutional edifice in the United States were Lockeian in spirit and letter (Mukherjee \& Ramaswamy, 2012: 208).

To achieve the objective of the research, the paper is divided into the following sections: Introduction followed by the section on constructing the Lockes' social contract-democracy nexus. The next section focuses on the challenges of democratic governance in Nigeria: Identifying Lockes' social contract principles as the missing link. The discourse ends with a closing remark.

\section{Constructing the Lockeian Social Contract-Democracy Nexus}

The simple task of this section is first of all present a general view of what the social contract theory entails and secondly present John Lockes' brand of the theory. And more importantly, the section will unveil the democratic content of the Lockeian social contract theorizing.

Though there are several contending philosophies about the formation of the state, however, the study focuses on the social contract theory (otherwise known as the contractarian- philosophy) due to its strong influence on nation states today. A close examination of the social contract theory, with its emphasis on consent of "men" (the society) as forming the basis of political legitimacy and authority, would link this age old theory to constitutional representative democracy form of government that exist presently (University of Pretoria, 2011). In other words, the social contract theory posits that due to the fact that men see the need, want and desire to be governed, they "agree" to elect a leader (or set of leaders), and willingly give up their power and authority to such said leaders to lead them. This said leader is construed in the form of present day democratic governments.

The term "social contract" refers broadly a situation whereby legitimate authority is derived from the consent of the governed. The consensus among social contract philosophers is that the governed (the people) decide to voluntarily give up the freedom of action that they have under the "natural state" as humans, in order to obtain the benefits provided by the formation of social structures and broad class of philosophical theories, which have as their subject, the implied agreement by which people form nations and maintain a social order (University of Pretoria, 2001:10). There are several numbers of postulates with certain differences to be found in this broad definition. The term "social contract" is actually used to describe these broad classes of philosophical theories that have the implied agreement of people to form nations and maintain a social order as part of their essence. This generally means that the people give their right to a "government", to a "sovereignty will" or a "sovereign authority". The "sovereign will" has been defined variously to be the king (in the case of a monarchy), a council (in the case of oligarchy) or the majority (in the case of a democracy or republic). These differences in ideas as to who constitutes a sovereign will, coupled with the mode of formation of society, is what underpins the different theories of social contract (The Social Contract theory, 2006). Put differently, the social contract theory posits that political legitimacy, political authority, and political obligations are derived from the consent of those who create a government and who operate it through some form of quasi-consent, such as representation, majoritarianism, or tacit consent. This implies that legitimacy and duty depend on consent, on a voluntary individual act, or rather on a collection of voluntary individual act (Riley 1982:93).

Apparently, social contract theorists advance the view that the state or, more precisely, civil society is the product of a contract, a covenant, an agreement, or a compact. Nbete (2012:271) argues that its earliest recognizably modern form dates back to Thomas Hobbes and continues with the works of John Locke, Baruch Spinoza, Samuel Pufendorf, Jean - Jacques Rosseau (and others) to Immanuel Kant; whilst John Rawls stands out among its contemporary proponents, not only for resurrecting the social contract theory from the dispute into which it fell after Kant but, perhaps more importantly, for incorporating into it some key elements for its adaption to the contemporary requirements of the state and citizenship. Essentially, the central idea of contractualism is the legitimacy of the state and/or the principles of sound justice derive their legitimacy from a societal agreement or social contract (Nbete, 2012:271). Though the above contractualists were all proponents of the social contract theory, but they differ on how they arrived at the political society and as well as what constitute and how the political society is managed.

Like Hobbes and other contractualists, Lockeian conception of the social contract was a derivative of his perception and description of the state of nature which was also dependent on how he conceived human nature. Locke considered human beings as pretty decent fellows, far removed from quarrelsome, competitive, and selfish creatures of Hobbes. Locke believed that desire is the main string of all human acts and a feeling of pleasure comes from when desire is satisfied. The purpose of all human action is the acquisition of pleasure and avoidance of pain. Locke believed in the goodness of human nature. Accordingly, to him, men are basically 
decent, orderly and society-loving, capable of ruling themselves. Rationality is a pervasive characteristic of man. According to Locke, the individual can live in a moral way even without the state. It is this light of reason which he calls the "spark of divine nature" that enables man to discern and follow the law of nature which is behind all things. Consequently, the state of nature according to Locke is not a state of war but one of peace, goodwill, mutual assistance and preservation (Mahajan, 1988:234 - 235).

According to Locke, the SON, the natural condition of mankind, was a state of equality and freedom, that is, is a state of complete liberty to conduct one's life as one best sees fit, free from the interference of others. Implying that the individual was endowed with sound natural rights. To quote Locke:

The state of nature has a law of nature to govern it which obliges every one; and reason, which is that law, teaches all mankind who will consult it, that being all equal and independent, no one ought to harm another in his life, health, liberty, or possession (cited in Mahajan, 1988:235).

Invariably, while the SON of Hobbes was both pre-social and pre-political, that of Locke was only prepolitical. According to Locke, people lived in society in the SON. Individuals were social and had rights and liberties. Locke went on further to defend personal independence and freedom as fundamental human rights. No individual had right to coerce or dominate another in the SON. Everyone had an equal right to one's natural freedom, without being subjected to the will or authority of any other man. Locke asserted that the laws of nature were those that reason dictated. Since right and duty of self-preservation were derived from the laws of nature, the most important of these was the right to hold others responsible for a breach of the law and to punish them accordingly (Mukherjee \& Ramaswamy, 2012:218).

Basically, to say that a right is "natural" is to say that is self-evident, pre-legal or moral rights. This means that it existed prior to and independently of the legal and political institutions of any given society. The natural rights Locke identified in the SON were principally the rights to life, liberty and property. There are two other rights Locke identified that everyone enjoyed in the SON: the right to punish anyone who transgress the law of nature (including those who violate the rights of others), and the right to exact redress or compensation from those who have violated one's own natural rights (Nwosu, 2006:201).

Locke also cautioned that the SON was not one of the licence, for though the individual was free from any superior power, he was subject to the law of nature. According to Locke:

Though the state of nature be a state of liberty, yet it is not a state of licence, that man in that state has uncontrollable liberty to dispose of person or possessions, yet he has no liberty to destroy himself or so much any creature in his possession but where a nobler use than its above preservation calls for it (cited in Mahajan, 1988:235)

From the laws of nature, individuals derived the natural rights of life, liberty and estate (collectively called property). The laws of nature were known to human being through the power of reason, which direct them towards their "proper interests". For Locke, liberty was not the freedom to do what one chose, but to act within the confirms of the laws of nature. Freedom presupposed order and was possible only within a framework of law. In the absence of law there was no freedom. Law granted freedom as it kept individuals from being subject to the arbitrary will of another person. For Locke, liberty was personal independence and thus ruled out slavery as it meant subjugation to the arbitrary will of another person: liberty was to be free from restrain and violence by others, which cannot be, where there was no law. In an explicit manner, Locke stated that freedom as the "liberty to follow my own will in all things, where the rule prescribes not; and not to be subject to the inconstant, uncertain, unknown, arbitrary will of another" (cited in Mukherjee \& Ramaswamy, 2012:218).

In order to drive home the sacrosanct nature of the natural freedom, liberty and equality of individuals, Locke had to argue that it was a product of divine moral principles. He asserted that SON was not only a state of perfect freedom, but also a state of perfect equality. Individuals had equal right to natural freedom. As a true Christian, Locke believed that God created human beings equally, that is, as well as each individual was subject to the laws of nature, they also had equal right to enforce the law and punish the transgressors (Agu, 1996:87). For Locke, political authority was ultimately based on religious obligations, which were the source of all morality. Unlike Hobbes, who argued for an unlimited right of nature that each individual could claim, Locke stressed on a natural duty of self-preservation owed to God for having created us. According to Mukherjee and Ramaswamy (2012:218), this duty ruled out strife, for not only did we need to preserve ourselves, but we also needed to perceive the fact that we were all equal before God. The SON was therefore moral. Political authority for Locke was not mere power, but power with right and responsibility. A right could only originate from an already existing right, and because individuals had no right to give away their duty to preserve themselves they could not therefore morally or logically grant rightful power to an absolute authority. This is understandable because Locke also holds that the rights of life and liberty are "inalienable", meaning that they cannot be waived or transferred. And the reason why they are inalienable according to Locke is because we all are God's property. As a result, Locke viewed absolute political power as illegitimate, for it was tantamount to giving up to another a right which one did not have in the first place. To Locke, there was just the relationship between God and human 
beings. All human authority and relationships were based on trust (Nwosu, 2006:68; Mukherjee \&Ramaswamy, 2012:220).

The main drawback of life in the SON is that human lives and property are not safe or secure there; because violations of the law of nature were not fully and consistently punished. In other words, though the SON was one of liberty and equality, it was also one where peace was not secure, being constantly upset by the "corruption and viciousness of degenerate men". It lacked three important wants: the want of an established, settled known law; the want of a known and indifferent judge; and the want of an executive power to enforce just decisions (Mukherjee \&Ramaswamy, 2012; 220). In similar vein, Sabine and Thorson (1973:485) averred that the defects of the SON lies in the fact that it had no political institutions such as magistrates (impartial and indifferent judge), written law (an established settle and known law), and fixed penalties (the absence of executive powers to enforce just decisions) to give effect to the rule of right. As a result, life in the SON was inconvenient because each individual had to interpret the law of nature for himself and had also to enforce it without the help of any other authority.

Invariably, the compulsion to constitute a civil society was to protect and preserve freedom and to enlarge it. Through the SON, Locke tried to tell us the meaning and importance of authority, namely that individuals came together to ensure the observance of the laws of nature, to guarantee the greater possibility of impartiality in the implementation and execution of rules that govern common life, and thereby increase the chances of peace that impartiality entailed.

To deal with the issue of inconveniences of the SON, Locke constructed two contracts: Social contract and governmental contract. Social contract led to the formation of civil society and the government contract to the establishment of the government (Mahajan, 1988:235). The first contract was among the people themselves and the second between the people in their corporate capacity on one hand, and the ruler on the other hand (Asirvatham \& Misra, 2000:102). The social contract put an end to the primitive SON. Society is organised for protecting human life and safe guarding its property and freedom. Man does not give up all of his rights to society but only the rights of health, liberty and possession. Anybody who disobeys is liable to be punished by society. Society transfers some of its power to a selected few persons who form the government. The ruler and the people enter into this contract. Thus, for Locke, the purpose of individuals entering into social contract that creates the government is to protect their natural rights, especially their property rights.

The next task of the paper under this section is to unravel the attributes of Lockeian social contract and how these attributes resonates with the indispensable tenets or principles of contemporary constitutional representative democracy. One of the first attributes of Lockeian social contract is that he made the consent of the people the source of governments' legitimacy and authority. In other words, the selection of personnel of government, public policies and actions are based on the consent of the governed, which is determined by the majority of the members of society (Nbete, 2012:270). To quote Locke:

The community perpetually retains a supreme power of saving themselves from the attempts and designs of any body. Wherever they shall be so foolish or so wicked as to lay and carry on designs against the liberties and properties of the subject. Whenever anyone shall go about to bring them to slavish condition, they will always have a right to rid themselves of those who invade this fundamental, sacred and unalterable law of self-preservation (cited in Mahajan, 1988:236).

The governmental contract is subordinate to the social contract because the government is acting on behalf of the people. For Locke, the rulers hold power on fiduciary grounds and are accountable to the people. These provisions wherein the people choose and can remove their rulers constitute the source of the peoples' power.

In modern day representative democracy, democratic legitimacy or legitimate governance is said to exist when there is public participation or consent in the selection of public office holders as well as in the process of public policy making (Ocheje, 1999:165). Consent here means participation; that is, the governed must actively participate and not be excluded from the political and governance process. In other words, the people must "agree", "consent" or "give their mandate" to be governed in contemporary democracy is captured in their participation in the electoral process; either they are canvassing for political office or they are exercising their voting rights.

Popular consent which is a derivative of the active and full participation of the governed is very critical to the legitimacy of any democratic government; the health, stability and vibrancy of any democracy depends largely on the mandate or consent given to it through the meaningful participation of the citizenry in the political process. It is basically for this reason that Abraham Lincoln defined democracy as the government by the people, for the people and of the people. Invariable, democratic government exist primarily for the interest of the people. Participation by the governed is key to democratic governance, without it there will be no legitimacy (Inokoba \& Kalagbor, 2016:2). Participation of the governed means the governed have a say and consent to whatever decisions are ultimately made. This means that the process is democratic, because such decisions would have been informed, shaped or moulded by the participation of the people (Ocheje, 199:165). 
In Lockes' construction of his civil society and government, he also advocated for a limited constitutional and rule-based political authority (government). Simply put, Lockes' state is constitutionally limited, not absolute as recommended by Hobbes. Describing the attributes of a good state, Locke said it existed for the people who formed it, and not the vice versa. It had to be based on the consent of the people subject to the constitution and the rule of law. It will be limited since its powers were derived from the people and were held in trust. It was also limited by the dictates or provisions of the natural laws and natural rights and freedom of the citizens. Locke categorically asserted that supreme power resided in the people, and the people as a community had the inalienable right to institute and dismiss and replace a government. The government is like a trustee. If the government fails to protect the life of the people and safeguard their property and liberty, the people have the right to rise in revolt and dismiss it and replace it (Mukherjee \& Ramaswamy, 2012; 222; Mahajan, 1988:236).

Lockes' social contract and rule-based government obviously resonates with the fundamental tenets and principles of today's liberal and representative democracy. Like Lockeian state, modern democracy entails limited, consensual, constitutional and rule of law based government (Paki \& Inokoba, 2006:82-83; Enemuo, 1999:144-145). Democracy derives its power and essence from the people and provisions of the constitution. It defines the powers of the government and under a functioning democracy; the government must govern the people according to the limits of power allocated to it by the constitution. It is a government built on the rule of law - this ensures the supremacy of the law, equality before the law and the respect of the fundamental rights and freedom of the citizenry. Like Lockes' government which could be dismissed and replaced by the people, today's democratic governments could also be removed and replaced by the people through the instrumentality of elections. This is so because ultimate sovereignty resides with the people and the government exist for the interest of the people.

Another democratic principle associated with Lockes' state is that it is built on majority rule. Accordingly, to Locke, the people accepted (and were bound by majority rule) decisions, even if they personally disagreed. Both the majority and minority will continue to support the government as far its performance is satisfactory and in accordance with the natural laws of the state (Mukherjee \&Ramaswamy, 2012:222). Likewise, today's democracy is built on majority rule; this ensures that a significant number of the population participate in government. Invariably, governing power is in the hands of the majority, not a tiny minority. It is this principle that makes democracy an all-inclusive government (Paki \& Inokoba, 2006:82).

In his construction of the political authority, Locke also advocated for the entrenchment of the democratic principle of the separation of powers. In order to check the possible abuse of political power and the fundamental rights of the people by organs and agents of government. Locke recommended the separation of powers among organs of government thus pre-empting Montesquieu's theory of separation of powers which is now a cardinal principle of contemporary representative democracy. This democratic tenet which is characterized by the sharing or division of powers of governance among different arms of government ensures checks and balances in the use of power as well as enhances the respect for the rule of law (Paki \& Inokoba, 2006:82). This principle is enshrined in constitutions of democracies in order to check dictatorial tendencies of governments as well as protect and safeguard the fundamental rights of the citizenry.

Conclusively, one can say that the SON of Lock has a lot of similarities with today's liberal democracy for the following reasons: The state which is instituted by the consent of the people, exist for the people who formed it. Citizens do not exist for the state. The people also retain sovereignty (that is, power of governance) so they can decide to remove and replace any unpopular and anti-people government. The state is also a constitutionally limited one that is not absolute. It manages the affairs of governance based on the constitution and the terms of the mandate given to it by the people.

\section{The Challenges of Democratic Governance in Nigeria: Identifying Locke's Social Contract Principles As The Missing Link}

Democratic governance which the essay equates with good governance is seen as both a broad strategy and a particular set of initiatives to strengthen the institutions of civil society with the objective of making government more accountable, more open and transparent, more responsive to the needs of the people and more democratic (Inokoba \& Nwobueze, 2015:7; Lawal \& Owolabi, 2012:8).In essence, democratic governance is characterized by the following attributes: citizens participation and respect for the rule of law; transparent and accountable government institutions and processes; consensus and all-inclusive government; government that promotes equity and sound effective and efficient public policies that is responsive to the expectations and needs of majority of the citizens.

Therefore, every democratic government is judged or assessed according to the degree of its commitment to the ingredients of democracy. Democracy thrives where people freely stand for election and vote during election; where there are periodic elections based on universal suffrage; where the fundamental rights and freedom of the citizenry are respected and protected; where governments and its agents adhere to the rule of law; where majority decisions are ensured and respected; where politics is played with a sense of sportsmanship, tolerance and 
moderation; where elections conducted are free, fair and credible; where succession process is smooth and not problematic; and where the process of election is competitive among several political parties (Idada \& Uhunmwuangho, 2012:51). It is the existence of these democratic tenets in a political system that makes it a democratic system.

It was with this perception of the virtues of democracy that's Nigerians welcomed the Fourth Republic with a lot of expectations. However, twenty years of the Fourth Republic has woefully and visibly failed to approximate these expectations, dreams and yearnings of Nigerians. Almost two decades of formalistic democracy has failed to address the socio-economic and political maladies such as inadequate, failing and decaying infrastructure, skyrocketing inflation and unemployment, depreciating real income of workers, failed elections, violent and intolerant politics, insecurity, governmental abuse of citizens' rights, brazen impunity among public officials, political marginalization, suppression and injustice (Inokoba \& Kumokor, 2011:139).

Our central argument is that Nigerian democracy is going through this trial and crisis as a result of the near absence and / or absence of the indispensable ingredients of democracy in the politics (that is the political conduct of the political elites) and governance system of the Fourth Republic. Practicing democracy without the requisite principles, values and attitude has turned democracy in Nigeria into a sham. In constructing his political society (or state), Locke argued that for the state to achieve its ultimate objective of serving the interest of the citizens, it must be built on the following democratic principles: Government built on popular consent and effective participation; constitutionally limited and rule-based government; existence of the principle of separation of powers and; government built on majority mandate and interest. These are discussed in detail below.

\subsection{Government built on Popular Consent and Effective Participation}

One of the invaluable contributions of Locke's political philosophy to modern day representative democracy is the central role he allocated to popular consent in the establishment of the political authority. It is through the consent of the people that the social contract is established with the government, and it is through the instrumentality of popular consent that the government commands authority and legitimacy. In representative democratic state like Locke's polity, consent basically means the government derives its authority and power to govern from the mandate given to it by the people. This also connotes that in a democracy the governors or political leaders hold power on fiduciary grounds and are accountable and responsible to the people that gave them the mandate in the first place. In other words, governments in contemporary representative democracy primarily are put in place by the people and such governments will continue to enjoy the support of the people as long as it is protecting the interest and rights of the people.

If popular consent as advocated by Locke entails the mandate given by the people to be governed by whoever they choose, then we can conveniently aver that in today's democracy the principal medium through which the citizens give their mandate to be governed is the electoral process. It is through elections that the citizens or more specifically the electorates decide who should occupy vacant positions in government. The role election plays in democratic governance cannot be over-emphasized. Indisputably, election is the most foundational element of modern day representative democracy especially as it regards the role it plays in creating a social contract between the citizens and government through popular consent (Paki \& Inokoba, 2006:182; Alapiki, 2004.130).

More so, most political offices are filled through the electoral process. This makes free, fair and credible election as one of the most indispensable tenets of participatory democracy. Unfortunately, this is one of the major debacles to democratic consolidation and governance in Nigeria since it became an independents nation. The President and Vice President at the Federal levels; the Governor and Deputy Governor at the state level; and the Chairman and Councillors at the Local Government level and the members of the legislative houses National Assembly (the Senate and House of Representatives) at the Federal level, the state Houses of Assembly and Legislature, Councils of the Local Governments are all filled by elections. However, the electoral process and political party system are all corruption ridden and not sufficiently participatory (Olu-Adeyemi, 2012: 168; Azinge, 2004; 57). Thus since the inception of the Fourth Republic in Nigeria though there has been orderly and successful transition from one civilian government to another, the same cannot be said of the elections that brought these administrations to power. Like previous republics, elections in the Fourth Republic Nigeria are characterized by serious and blatant cases of electoral corruption such as stuffing of ballot boxes; manipulation of voters register; buying of voters cards by politicians, special treatment of voters and election officials; underage voting; disappearance or destruction of ballot boxes; the stealing of electronic card reader and other electoral materials; distortion of results; intimidation and harassment of political opponents by security agents and thugs as well as election related violence, killing and arson (Inokoba \& Nwobueze, 2016: 6). All the above undemocratic, criminal and illegal electoral acts are not mere fallout of administrative lapses of the electoral umpire, rather they are measures deliberately designed and orchestrated by unscrupulous politicians especially political godfathers to illegally capture political power (or sway electoral victory to a desired and unpopular 
direction) (Inokoba \& Nwobueze, 2016.6)

In investigating the history of elections in the Fourth Republic, there is a general consensus that the integrity of elections has been on the decline since 1999 with the 2003 and 2007 general elections widely assessed by both local and international observers as the worse in the country's history. Even the just concluded 2015 General Elections that were acknowledged as generally peaceful and credible (largely as a result of the decision of an incumbent president to accept defeat for the very first time in Nigeria's political history) and more recently the 2019 elections, were also seriously marred by massive electoral fraud and pre-during-and-after election violence.

The adverse impact of electoral corruption on participatory democracy and governance in Nigeria is not farfetched. Electoral corruption especially its violent manifestation has disenfranchised and deprived the Nigerian people their democratic rights to freely, without fear or favour elect those that will govern them. It is a common knowledge in Nigeria that politicians and their political patrons in an attempt to achieve their personal ambitions, capture and monopolizes the political space through massive commercialization and monetization as well as aggressive militarization of the electoral processes thereby encumbering scrupulous Nigerians from taking part in the electoral process. As a result of the commercialized, combative and exclusionary nature of elective politics in Fourth Republic democracy in Nigeria successive civilian governments have come on stream without the consent and mandate of majority of Nigerian people. It is therefore not surprising that the Human Rights Watch asserted in its world survey that the greatest form of human rights abuse going on in Nigeria is that Nigerians have been continually denied the right to choose their leaders through a credible, free and fair election. Rather most of the so-called political leaders are selected and imposed on the people by political strongmen (or godfathers) with the consequence that those in power are not considered true representatives of the Nigerian people (Agbo, 2009.54).

One immediate adverse effects of elections devoid of popular participation and mandate is that its byeproduct, that is, the government will be deprive of a social contract with the people. And because most governments in Fourth Republic Nigeria were midwifed through fraudulent and undemocratic elections devoid of social contracts with the people, they have been distinctively exclusive, dictatorial, lawless, corrupt, predatory and unresponsive to the needs and yearnings of the Nigerian people. Again, because these governments are bereft of social contract with the Nigerian people, they have found it difficult in most instances to exercise hegemonic authority over the people they govern. This crisis of legitimacy is characterized by unending industrial disharmony, discontented civil society, ever-present ethnic nationalities dissatisfaction and quest for political autonomy and the ever-increasing number of ethno-religious militia groups such as Movement for the Emancipation of the Niger Delta (MEND), Niger Delta Avengers (NDA), Independent People of Biafra (IPOB), Boko Harm and several others. All these challenges to the Nigerian state are evidences that the several governments are disconnected from the people as a result of the lack of requisite mandate to govern.

\subsection{Constitutionally Limited and Rule-Based Government}

In his construction of his civil society and government, Locke advocated for a limited constitutional and rulebased political authority. Since government exist for the people who formed it and not the vice versa, the governing powers of such government must be limited by the dictates of the constitution and the rule of law. Likewise, too, democracy right from its medieval conception to its contemporary manifestation has been described as a constitutionally limited government that is built on the rule of law (Paki \& Inokoba, 2006:82-83: Enemue, 1999:144-145). This is so because democratic government derives its power and essence from the consent of the people and provisions of the constitution. So it is a government that must govern the people according to the limits of powers allocated to it by the constitution.

However, twenty years of democracy in Fourth Republic Nigeria has woefully failed to approximate the lofty democratic principle of respect for the rule of law. Like its military progenitor the governments in the Fourth Republic Nigeria have not shown respect for the rule of law especially with respect to judicial decisions and due process in governance as well as the protection and safe guard of the rights and freedom of majority of powerless Nigerians. Scholars have attributed these lawless and dictatorial tendencies of governments to more than twenty-nine years of military regime that was characterized by a culture of impunity and the personalization of political power. Hence, politicians mainly made up of military generals and their civilian associates have carried over this military culture to corrupt the democratization and governance processes of the Fourth Republic (Inokoba \& Nwobueze: 2015:13; Oke, 2010:35: Alapiki, 2015:57).

Since the emergence of the present democratic dispensation, all tiers and arms of government have found it difficult to carry out governance according to the provisions and dictates of the laws of the land. No administration is spared; the various presidents, governors, local government chairmen, legislators of all tiers of government, political appointees and security personnel are all guilty of this act of disrespect for the rule of law and abuse of the fundamental rights of Nigerians. The disrespect and abuse of the laws of the land takes several form: the criminal usurpation of the inalienable rights of Nigerians to elect their leaders by powers political 
figures; brazen political corruption such as the looting of the common wealth by political leaders and spending of public money without legislative backing and spending far and above approved budget by the executive; award of contract without regards to due process: violation of the principle of separation of powers mainly by the executive; disrespect for unfavourable judiciary decisions; fighting political corruption and economic crime without due regard to rules and laws of the land; misuse of security and military personnel as private security guards for the protection of highly connected individuals and several other forms of violation of the constitution of the Federal Republic (Inokoba \& Nwobueze, 2015:14)

Despite the almost twenty years of democracy in Nigeria the respect, protection and safe guard of fundamental human rights is still a major challenge. For instance, the protection and enjoyment for the right to life and respect for human dignity is hampered by non-availability of necessary socio-economic infrastructures that can guarantee the realization and fulfilment of such right (Olu-Adeyemi, 2004:169). The Fourth Republic governments have failed in a lot of ways to ensure the protection of the rights of the citizenry from power drunk and oppressive politicians, security and military personnel and agencies of government. At present the fundamental rights of Nigeria still come under attack from personal and agencies of government as evidenced in the Buhari's administration refusal to obey unfavourable court decisions; the lawless procedures of fighting corruption; abuse of the rights of internally displace persons (IDPS) as a result of the Boko Haram insurgency and the lawless and brutal manner of its war against the Boko Haram insurgents (Inokoba \& Nwobuoze, 2015;13).

According to the Centre for Democracy and Human Rights (CDHR) (cited in Olu-Adeyomi, (2004:169), other traditional means by which political office holders and agencies of government abuse the rights of Nigerians to life and human dignity include: death penalty, extra judicial killings, including assassinations; arbitrary arrest and detention; unresolved disappearances; avoidable disasters and poor administration of the prison system. A more worrisome violation of the right to life and property is the deployment of the security and military personnel and their instruments of violence against Nigerians to cause colossal destruction of lives and property. A good example of this is the crime against humanity military massacre carried out by the erstwhile Obasanjo's presidency against the people of Odi in Bayelsa State and Zaki Ibiam in Benue state (Inokoba \& Nwobueze, 2015:16) and as well as the more recent invasion and ransacking of Bilabiri community in Ekeremor Local Government Area of Bayelsa State.

The foregoing scenario of the brazen disrespect of the rule of law and more so, the abuse of the rights of Nigerians to life, dignity and good life by the personnel and agents of the Nigerian state is a major affront on one of the cardinal principles and core values of democratic government as espoused by John Lockes social contract, which is respect for the fundamental rights of the citizens and their wellbeing. Thus, the despotic and oppressive nature of governance in the Fourth Republic Nigeria characterized by wanton abuse of the fundamental rights of Nigeria citizen has become one of the several maladies and anomalies bedevilling democratic governance in Nigeria

\subsection{Respect for the Principle of the Separation of Powers}

Another cardinal virtue of democracy that was espoused by the Lockes social contract was the democratic principle of separation of powers. The theory of the separation as propounded by Montesquieu was basically meant to check the excesses of government; that is, limiting the different organs and structures of government to the constitutionally assigned roles. Ultimately, in a democratic setting, it is meant to enhance the observance and respect of the rule of law as well as protection and safe guard of the rights and freedom of the citizens.

One of the principles of democracy that has become a victim of political leaders and government disrespect for the rule of law is the principle of separation of powers. This principle was meant to ensure checks and balances among organs and branches of government as well as mutual respect for each other in the operations of government. It was also meant to ensure equity and balance of power among the different organs of government in such a way that none can super impose, and assert its will and interest on other branches or levels of government.

The rule of law thrives in a state, where there is a separation of powers among the main organs of government, namely the executive, the legislature and the judiciary, so that the power of law making, executive and adjudication are not concentrated on one person or group of persons. Absolute power, argues Lord Action corrupts absolutely. To avoid tyranny and oppression of the citizens, he argues, the rule of law should equally embody the separation of powers so that each organ or arm of government shall be a check on the excesses of the other arms. It is on this premise that democracy can thrive in a state. (Nwekeaku, 2014:28).

A functional separation of powers ensures checks and balances among the executive, legislature and judiciary; it ensures that none of the organs appropriates the powers of the other organs. Even on this indispensable principle of democracy, Nigeria's Fourth Republic is found wanting. This in a lot of ways explain why governance is characterized by lawless, impunity and why the rule of men always takes precedence over the demands of the rule of law in the Fourth Republic democracy. Under this condition, promotion and protection of 
the fundamental human rights of the citizens becomes difficult.

Hence, one of the several maladies weakening democratic governance in the Fourth Republic is the overbearing, suppressive and suffocating tendencies of the executive arm of government on the other arms and agencies of government. Political commentators and scholars alike, attributes the executive dominance to its control of the financial purse (or financial resources), monopoly of the instrument of coercion (or force) and the underdeveloped nature of politics in Nigeria like any other Third World country. The legislature and the judiciary alike, depend a lot on the resources and privileges that are under the control of the executive branch of government. One administration that was notoriously known for its strangle hold, domination and manipulation of other organs of government was the heavy-handed Obasanjo's administration. Under Obasanjo's presidency, there was so much political tumult and unprecedented leadership turnover at the National Assembly (NASS) as a result of his unwholesome and overbearing attempts to put the leadership of the NASS under his control particularly during his attempt to achieve his third term agenda. Obasanjo was also known to have extrajudicially used the legislative and judicial arms to unconstitutionality impeach several unfriendly state governors such as Chief D.S.P. Alamieyeseigha of Bayelsa State, Peter Obi of Anambra, Ladoja of Oyo, Joshua Dariye of Plateau, among others. The state tier of government also leaves so much to be desired as States Houses of Assembly and Judiciary have become appendages of the executive arm under the governors of the respective states. A good example of state governors' lawless rascality against other arms of government was the Governor Rotimi Amechi's indefinitely closure of the Rivers State House of Assembly and judiciary for some undisclosed reasons. This executive action of the governor was a serious breach on the rights of the people to fair hearing in the law courts as well as a violation of people's right to the freedom of movement as the accused were detained in prions indefinitely beyond legally permitted period as a result of the indefinite closure of the law courts by the state governor.

The Buhari administration has also had its fair share of the abuse or disrespect for the principle of the separation of powers. A ready example is the October gestapo and nocturnal invasion and arrest of serving judges by the DSS (Directorate of State Services) over allegations of bribery and financial impropriety. Though the government justified its unwholesome action as part of its war against corruption but the enlightened and critical public sees it as a desperate attempt by the Buhari's presidency to stampede and coerce the judiciary to be favourably predispose to the government especially in its unending election related court cases it has with its major rival political party - the people's Democratic Party (PDP).

From all the cases mentioned above, it is clear that whenever the executive arm of government refuses to be guided by the principle of separation of powers in its relations with the legislature and judiciary, the rule of law suffers and at the long run the citizens' rights and freedom also suffers. This is one of the major paradoxes of the Fourth Republic democracy in Nigeria.

\subsection{Government Built on Majority Mandate and Interest}

Democracy right from its classical Greek model is perceived as a government system that built on the participation of majority of the citizens in the section of political office holders as well as directly or indirectly the direction of public policies. In other words, as a participatory governance process, the selection of the personnel of government and its policies are mainly decided by majority decisions of the people. Locke in his social contract and government viewed this ideal as a cardinal principle that will ensure the state enjoys legitimacy, stability and support of the people (Mukherjee \& Ramaswamy, 2012:222). Likewise, in contemporary representative democracy the governing power is expected to be in the hands of majority, and not under the control of a tiny minority of vested interests. It is this ideal that makes democracy an all-inclusive government (Paki \&Inokoba, 2006:82).

More so, genuine majority rule and inclusive government is not build on a political vacuum. It is a product of a political environment where there is integrity of the electoral system and process. That is, a situation of free, fair and credible elections where, the peoples vote translates to political power. The majority principle of democracy can also be ensured by the decision of the political contestants to play the game of electoral politics by the stipulated rules. In other words, to uphold the principle of majority mandate and rule, the politicians must be ready to respect the electoral choices of the people.

Arguably, the Fourth Republic political environment is devoid of the conditions that will encourage the institution of majority rule principle of democratic government. As earlier reiterated, electoral corruption orchestrated and masterminded by the electoral competitors and their political godfathers has made it almost impossible for majority of Nigerians to effectively take part in the electoral process and the wider political system. Through massive commercialization, monetization and militarization of the electoral processes by politicians and their godfathers, majority of Nigerians have been effectively prevented from deciding who should govern them. More so, through well-orchestrated process of buying up political offices (at the political party level), bribing of electoral officials, security personnel and prospective voters as well as the use of violence to intimidate and scarce away intending voters from exercising their franchise, political contestants and godfathers 
have turn electoral politics to not only dangerous venture but also criminal and capital intensive business venture which can only be undertaken by the rich, mighty and unscrupulous (Inokoba \& Nwobueze, 2016:18). Like in the Anambra scenario, it is a known fact that the incumbent godfather, Chris Uba bought 22 out of the 24 seats in the Anambra state House of Assembly, and virtually all the state seats in National Assembly. It is also on record that the three senators for the state neither campaigned, printed posters nor contested the elections. They were handpicked and imposed on the people by Uba (Adeoye, 2009:369). It is basically for this reason that after successfully installing their preferred candidates (their godsons), godfathers can publicly ascribe such electoral victories to their influence and power. The Chris Uba's public declaration that he was responsible for the institution of Ngige as Governor and majority of other successful politician readily comes to mind (Inokoba \& Nwobueze, 2016:17)

There is no gainsaying that this kind of elitist, plutocratic, corrupt, violent and exclusionary elective politics does not augur well for the enthronement of the democratic principle of majority mandate and government. Apparently, for almost twenty years of the Fourth Republic, Nigeria has been "democratizing" without the involvement of majority of Nigerians. It is basically for this reason that Nigerian democracy has been described as elitist, plutocratic and illiberal.

\section{Closing Remark}

From the analysis presented so far, democratic governance in Nigeria is flawed, problematic and bedevilled with a lot of maladies. What this paper has attempted to do is to explain the crisis of democratic consolidation and governance in Fourth Republic Nigeria by tracing it to the absence some of the prerequisites of the Lockeian social contract which now forms some of the indispensable tenets and values of modern day representative democracy. From our interrogation of almost twenty years of democratic governance in Fourth Republic Nigeria, it is glaring that the practice of democracy in the country is devoid of most of the irreducible and fundamental tenets of democracy as contained the Lockeian social contract; among these include the absence of transparent, credible, fair and peaceful electoral system; the absence of government built on popular consent and effective participation of the citizenry; absence of constitutionally limited and rule-based governments that have no respect for the principle of the rule of law; absence of government built on majority mandate and interests and as well as the disrespect for the principle of separation of powers. The prevalence of these anti-democratic and lawless political practices and culture in the governance process in Nigeria has further hindered the deepening of democratic culture and institutions in the country. And in the absence of strong democratic structures, strong political personalities have emerged in Fourth Republic Nigeria; over the years these strong men have contributed immensely to the weakening of democratic institutions in the country by carrying out governance according their wimps and caprices. The conclusion is that until Nigeria is able to put in place strong institutional structures that will ensure the enthronement and observance of the democratic principles of the Lockeian social contract, the country will continue to contend with the phenomenon of undemocratic and failed governance and politics.

\section{References}

Adeoye, O.A. (2009). "Godfatherism and the future of Nigerian Democracy". African Journal of Political Science and International Relations, 3(6), 268-272.

Agbo, A. (2009, June 8). "A Catalogue of Failures". Tell Magazine, P.37.

Agu, S.N. (1999). The Resolution of the Dilemma of Citizens Under Unjust Regimes: $\quad$ A Groundwork for Nigeria's Political Stability and Socio Economic

Development Lagos: Helen Roberts Research and Resources Limited.

Alapiki, H.E. (2015). The State and the Culture of Terrorism in Nigeria: Unveiling the Real Terrorists. Inaugural Lecture Series (No. 117) of the University of Port Harcourt.

Asirvatham, E. \& Misra, K.K. (2009). Political Theory. New Delhi: Schand and Company Limited.

Azinge, E. (2004). Law, Money and Politics. Ibadan: Epiphany Press.

Enemuo, F.C. (1999). "Democracy, Human Rights and the Rule of Law”. In Anifowose, R. \& Enemuo, F. (Eds.) (1999). Elements of Politics. Lagos: Malt House Press Ltd.

Idda, W. \& Uhunnwuaugho, S.O (2012). "Problems of Democratic Governance in Nigeria: The Way Forward". Journal of Sociology and anthropology, 3(1), $49-\quad 54 . \quad$ www.Krepublishers.com/02.../JSSA-03-1049-Idada-W-It.pdf.

Inokoba, P.K \& Nwobueze C.C (2016) "Godfathers, Electoral Corruption and National Security in Nigeria: The Fourth Republic in Focus". Being a Paper Presented at the 2016 Society for Peace Studies and Practice (SPSP) $10^{\text {th }}$ International Conference and General Assembly at Grand Hotel, Asaba with the Theme: Curbing Corruption and Building Sustainable Peace. Date: $15^{\text {th }}-17^{\text {th }}$ August,

2016.

Inokoba, P.K. \& Kalagbor, S.B. (2016). "Political Participation and Grassroots Democracy in Nigeria: Insights 
from Kolokuma/Opokuma Local Government Area of Bayelsa State”. Being a paper presented at the First International Conference on Politics, Security and Development. Under the Auspices of the Department of Political Science and Public Administration, Babcock University with the Theme: Forty years of Local Government Reforms and Democratic Development in Nigeria: Critical Perspectives. Venue: Babcock Business School Auditorium.

Inokoba, P.K. \& Kumokor. I. (2011). "Electoral Crisis, Governance and Democratic Consolidation in Nigeria". Journal of Social Sciences, 27(2), 139-148.

Inokoba, P.K. \& Nwabueze, C.C. (2015). "Ethical Deficit in Leadership: A Constraint to Democratic Governance in Nigeria's Fourth Republic". Being a Paper Presented at the $5^{\text {th }}$ International Conference of the Faculty of Social Sciences, Ignatius Ajuru University of Education, Port Harcourt with the Theme: Bridging the Gap in Africa's Development. Date: $26^{\text {th }}-29^{\text {th }}$ July, 2015.

Lawal, I. \& Owolabo, D. (2012). "Leadership Debacle: The Bane of Good Governance ～in Nigeria". AfroAsian Journal of Social Sciences, 3(3), 1- 12.

Mahajan, V.D. (1988). Political Theory. New Delhi: Rajendra Ravindra Printers.

Mukherjee, S. \& Ramasuramy, S. (2012). A History of Political Thoughts: Plato to Marx. New Delhi: PH1 Learning Private Limited.

Nbete .A. D. (2012). "The social contract theory: A model for Reconstructing a True Nigerian Nation-State". International Journal of Humanities and Social Science, 2(15), 267-278 www.ijhhssnet.com/journels/vol.2 No. 15 August 2012/3A.pdf.

Nwekeaku, C. (2014). "The Rule of Law, Democracy and Good Governance Nigeria". Global Journal of Political Science and Administration, 2(1), 26-35. www.eajournals.org/.../The-Rule-of-Law-Democracyand-Good-Governance-in-Nigeria.pdg.

Nwosu, O.S. (2006). State and Morals: An Introduction. Owerri: Spring field Publication.

Ocheje, P. (1999). "Exploring the Legal Dimensions of Political Legitimacy. A Rights Approach to Governance in Africa”. In Quashigah E.K. \& Obiora, C.O. (eds) (1999). Legitimate Governance in Africa: International and Domestic Legal Perspectives. Longman: Ibadan, 165-166.

Oke, L. (2010). "Democracy and Governance in Nigeria's Fourth Republic". African Research Review, 4(3a), 31 -40 .

Olu-Adeyemi. L. (2004). "The Challenges of Democratic Governance in Nigeria". International Journal of Business and Social Science, 3(5), 167-173. Ijbasnet.com/journals/vol.3.No.5March.2012/19pdf.

Omenka., J.I \& Akaan, R. (2013). "Leadership Democracy and Implications for National Development in Nigeria". In Nwanegbo, J.C., Omadachi, O., Tsuwa. J.T. (Eds) (2013). Discourses in Governance, Democracy and Development in Contemporary Nigeria. Abuja: SAP Publishing House.

Paki .F. \& Inokoba, P.K (2006). An invitation to Political Science. Port Harcourt; Kemuela Publications.

Riley, P. (1982). Will and Political Legitimacy: A Critical Exposition, of Social Contract Theory in Hobbes, Locke, Rosseau, Kant and Hegel. New York: Harvard University Press.

Sabine; G.H. \& Thorson, J.L. (2 K173). History of Political Theory. New Delhi: Dryden Press.

The Social Contract Theory (2006). Hobbes V. Rosseau? An Analysis. Available at: http://www.scribd.com/doc/2910336/The-Social-Contract-Theory. Accessed 1/06/2019.

University of Pretoria (2011). Theories and Developments Guiding Constitutional Democracy. Available at doeplayer.net/22176430. Accessed 1/06/2019 